\title{
The Role of Contemporary Islamic Movement towards Social and Political Changes of Modernity
}

\author{
Ibrahim Suleiman $^{1}$ \\ ${ }^{1}$ Department of Political Science, Bauchi State University, Gadau, Nigeria \\ Correspondence: Ibrahim Suleiman, Department of Political Science, Bauchi State University, Gadau, Nigeria, \\ Tel: +2348060287718, E-mail: isuleiman@ basug.edu.ng
}

Received: September 28, 2017

Accepted: September 30, 2017

Online Published: October 7, 2017

\begin{abstract}
This paper studies the role of contemporary Islamic movements towards social and political changes of the 21st century. Contemporary Islamic movements is a modern phenomenon; it is rooted in the historically and spatially recurring cyclical phenomena of "reform" (Islah) and "renewal" (Tajdid) which provide the models and symbols that link modernity to authentic elements of Islamic teachings. The study employs secondary source as a method of data collection. Based on these past rejuvenations, contemporary Islamic scholars are interacts with modern cultural, social, political and religious circumstances. While emphasizing the Unitarian and Universalistic character of Islam, it is also coloured by local variations. Some observers see Islamic movement as part of a trend in contemporary Islam toward a more orthodox and doctrinally homogeneous type of religion based on the sacred source-texts. This trend views local expressions of Islam as deviations from orthodoxy and seeks to suppress them. Modern means of communication have accelerated this process by opening up the periphery to the penetration of the centralizing forces. In this view, Islamic movement is more radical wing of the wider movement which also includes madrasah based traditional groups and Sufi type reform movements.
\end{abstract}

Keywords: Islamic Movement, Social and Political Changes, Orthodox and Doctrinally Homogeneous.

\section{Introduction}

Contemporary Islamic Movements in the $19^{\text {th }}$ and $20^{\text {th }}$ century is part of a wider religious resurgence extensive across the Muslim world. Contemporary Islamic movements is a modern phenomenon; it is rooted in the historically and spatially recurring cyclical phenomena of "reform" (Islah) and "renewal" (Tajdid) which provide the models and symbols that link modernity to authentic elements of Islamic teachings. Based on these past renewals, contemporary Islamic movements are interacts with modern cultural, social, political and religious circumstances. While stressing the Unitarian and Universalistic character of Islam, it is also coloured by local variations. Some observers see Islamic movement as part of a trend in contemporary Islam toward a more orthodox and doctrinally homogeneous type of religion based on the sacred source-texts. This trend views local expressions of Islam as deviations from orthodoxy and seeks to suppress them. Modern means of communication have accelerated this process by opening up the periphery to the penetration of the centralizing 
forces. In this view, Islamic movement is more radical wing of the wider movement which also includes madrasah based traditional groups and Sufi type reform movements (Tibi, 2000).

Contemporary Islamic Movement is an umbrella term for a wide variety of movements and discourse committed to Islam as a comprehensive total way of life and as a viable alternative to Western secular ideologies. Most of them are united in their goal of the Islamization of the social and political system of their societies, states, and ultimately of the whole Muslim world, yet there is a great diversity among them arising from the variety of local circumstances in which they emerged and operates. The goal of Islamic movement can be summarized as the re-establishment of a revived and authentic "true" Islam and its implementation in all areas of life. The best-known ideologue of the revivalists Muslim Brotherhood in Egypt, Sayyid Qutb, defined the goal of revivalist as:

“... The restoration of Islamic life in an Islamic society governed by the Islamic creed and the Islamic conception as well as by the Islamic Shari'ah and the Islamic system (nizam)" (Tibi, 2000).

The emergence of Islamic movement was due to the penetration of Western capitalist modernity into all aspects of Muslim societies from Arab world to Southeast Asia, a significant number of Muslim intellectuals began to write down the general outlines of a new intellectual project that is often referred to as "Islamic modernism." In the Arab world, Iran and the late Ottoman period was represented by such personalities as Jamaluddeen Al-Afghani, Muhammad Abdu, Muhammad Rashid Rida, Bediuzzaman, and Said Nursi, in the early phase and a host of other religious scholars and thinkers who were intent on finding a reconciliation between their grand Islamic tradition and the scientific and philosophical achievements of capitalist modernity. In South Asia, the project of Islamic modernism was represented by such thinkers and activists as Sayyid Ahmad Khan, Amir Ali, Mawlana Abu al-Kalam Azad, and others. In Southeast Asia, most notably in Indonesia, the project of Islamic modernism was represented by the Muhammadiyyah organization and its founder, Muhammad Dahlan (Abu-Rabi, 2006).

The major features of contemporary Islamic movement were as follows: (i) the revival of rational elements in the Islamic tradition, (ii) finding Islamic solutions to the challenges of the Western domination, (iii) embracing the philosophical and scientific features of modernity, (iv) constructing new academic and religious institutions to meet the challenges of modernity, (v) the revival of Kalam science, and (vi) the revival of Islamic languages and focus on foreign languages. Islamic modernism can be said to be composed of two major features at the beginning of the twentieth century: (i) In the first place it was deeply concerned with the foreign occupation and its intellectual and educational design aimed at eradicating foreign control. This was the case with the Muhammadiyyah; (ii) on the other hand; it saw the salvation of Muslims as being united with the foreign presence, as can be seen in the movement represented by Khan in India at the end of the nineteenth century. However, the logical outcome of both sides Islamic modernism was to lay down the blueprint for an independent homeland for Muslims in the Middle East, Southeast Asia, and South Asia (Ibid).

Moreover, the rise of nationalism in different parts of the Muslim world in the latter part of the nineteenth and early twentieth centuries, Islamic modernism paved the way for the foundation of the nation-state in the modern Muslim world. In Indonesia, for example, Islamic modernism combined with nationalism and the rise of other Islamist parties to power led directly to the creation of modern Indonesia. The same combination of factors can be seen in the case of Pakistan. Independence, national struggle, and the creation of modern institutions has been the landmark of contemporary Islamic thought. In the case of the Muslims of South Asia, the Partition of India and Pakistan has been a watershed in both contemporary Islamic intellectual and Indian intellectual histories. It 
is quite impossible to understand the huge issues hampering contemporary Islamic thought in South Asia without understanding this pivotal historical event and its intellectual, religious, social, political, and economic consequences and realities (Ibid).

\section{Contextual Historical Facts of Contemporary Islamic Movements}

Many people recognize the complexity and multiplicity of the causes that gave rise to contemporary Islamic movement; some are of the opinion that colonialism and modernization are the major causes of the resurgence. While others thinks about many factors which are as follows:-

\subsection{Reaction to Colonialism and Western Domination}

Colonialism brings about the Western cultural dominance which imposed secularization, dependence, and a division of life into separate secular and religious spheres. The famous Indian Islamic thinker Muhammad Iqbal (1877-1938) vividly expressed the commonly held view of the "insensitive multi-layered Western civilization" in its varied manifestations of capitalism, communism, secularism, and liberalism, challenging Islam of its inherent vitality. In sharp contrast to the miserable present, he recreated the memories of Islam's past glorious golden age. These two themes of anti-Westernism and reminiscence for the glorious past are characteristic of most contemporary Islamic movements.

Moreover, the movement provide "cultural authenticity, spiritual guidance, and practical help to those experiencing extreme frustration in their societies, and argues that these movements are not a passing phenomenon they are deeply rooted in Islamic history and culture and nurtured by the deep crisis in contemporary Muslim states. Also during the colonial period Islam as a political ideology was back staged as Western ideologies penetrated society. The failure of these Western ideologies to deliver following independence strengthened the Islamic movements with their call for a return to Islam as an authentic alternative political ideology.

President Khatami of Iran sounds a less hostile note while admitting that Muslims have lost their once dominant position in world history because of the political, intellectual, and technological ascendancy of the West. He states that "It is a fact that the West has given humankind many achievements, and also brought it many problems and difficulties". The problems faced by Muslims are common to Third World societies, and have been aggravated because while their private and social lives have been strongly influenced by the West, their culture belongs to another era. The crisis in non-Western peoples and countries is due to the fact that the culture which rules our lives or part of it is inconsistent with the civilization which more or less forms the basis of our everyday lives. This contradiction, which the West suffers from less, is the source of the serious crisis in the lives of most of us non-westerners (Enayat, 1982).

\subsection{Response to Devastating Change of Modernity}

Islamic movement emerged as a response to Western induced modern social and cultural changes that "threaten to dilute Islamic identity through the propagation of un-Islamic elements". Esposito, (1990) claims that the positive benefits of modernization benefited only a few, while the majority felt mainly its negative fallout rural migration and rapid urbanization, the breakdown of traditional family values, and a general climate of disillusionment and misery. Deukmejian, (1985) also stresses the negative social and economic effects of modernization which included the population explosion, the breakdown of traditional religious and social values, high unemployment, and the sharp inequalities in wealth distribution. These overwhelmingly rapid economic, social and cultural changes resulted in an acute sense of dislocation, identity loss, alienation and anomie (Ibid). 


\subsection{Reaction to Failed Islamic Liberalism}

Contemporary Islamic movement also came as a reaction to the failures of Islamic liberalism in the $19^{\text {th }}$ and $20^{\text {th }}$ centuries, as well as to the failures of nationalism and socialism after independence. Islamists compete both with the modernists, who accept a broad interpretation of Scripture and adopt some Western values, and with the secularist-liberals who argue for a democratic, pluralist state on the Western model. Islamists reject these worldviews and seek a return to the original sources of Islam, whilst claiming the right to re-interpret them (ijtihad) and reapply them to contemporary contexts (Ibid).

\subsection{Crisis of Legitimacy in Secular Nation-States and Regimes}

Another cause is the persistent crisis expressed by the weak legitimacy of the very idea of the nation-state as well as of the existing secular regimes. This crisis is evident in the pervasiveness of autocratic regimes and in the continuing segmentation of society along tribal, ethnic, and religious lines. The political, social, and economic failures of the secular state is seen as an important contributor to the rise of Islamic movement as a mass-based response demanding radical change. Islamists tend to blame the modern secular nation-state and its Westernized elites for the entire problem faced by the society (Ibid).

\subsection{Direct Political Catalysts}

The Arab defeat in the 1967 war against Israel, the secession of Bangladesh from Pakistan in 1971, the Lebanese civil war in the mid-1970s, and the Soviet invasion of Afghanistan in 1979 were catalysts in the spread of Islamic movement especially in the $20^{\text {th }}$ century. They added to the sense of backwardness, humiliation, impotence, and loss of self-esteem, with the resulting hostility aimed against local regimes that had failed to respond to the need of their societies, as well as against the superpowers and the West in general. Muslims of all classes and ages turned to fundamentalist Islam for a solution (Ibid).

\subsection{Nineteenth and Twentieth Century Contemporary Islamic Thinkers}

The reformers searched for a solution to the political and religious crisis caused by Western imperialism, and for an answer to the question of what had gone wrong with Muslim society. Against the secularists who blamed traditional Islam for the decline, and advocated the separation of religion from the state on the Western model; and the conservatives who advocated a rejection of the West, non-co-operation with the new rulers, and an isolationist withdrawal into traditional religion; the reformers offered an alternative both to Westernized secular adaptation and to conservative rejectionist. They initiated a process of internal self-criticism, of redefining Islam, and proving its relevance to the new context by a synthesis of Islamic and modern concepts. They instilled in Muslims a pride in their past glory, reviving their shattered sense of identity and their confidence. They also emphasized the progressive and rational character of Islam that enabled it to integrate modern culture and accommodate change. The reformers rejected common law, popular sufipractices, as well as the classical innovations of the ulamaand the four legal schools madhahib((Zeenath, 2005).

2.6.1 Jamal al-Din Al-Afghani (1839-1897) was a political activist who aroused Muslims to resist imperialism, revive their lost glory, and liberate their states from colonial rule by uniting the Ummah (pan-Islamism), reforming a decadent and superstitious Islam that had capitulated to Western influences, and by utilizing Western science and philosophy. He tried to bridge the gap between modern secularists and religious traditionalists, stressing that reason had been integral to early and classical Islam and that Islamic essentials are compatible with science. Islam is a comprehensive way of life encompassing the societal and political as well as the personal spheres. It is a dynamic and progressive religion of reason and science capable of responding to modern contexts. Islam is the real source of the Ummah's strength and Islamic identity and solidarity must be 
vigorously restated. The stagnation of Islam must be rejected, and the gates of ijtihad reopened so as to break the ulama's monopoly on religion and to formulate new responses to changing circumstances based on the original source (Harris, 1964).

2.6.2 Muhammad Abduh,(1849-1905) who became rector of al-Azhar and chief sharia judge (mufti) of Egypt, advocated reform by a return to the pure sources. He saw the causes of stagnation in Muslim society as lying in un-Islamic practices and superstitions, fatalism, and rigid scholasticism (taqlid); the corruption of the 'Ulama' and their subservience to the political leadership, as well as their inability to distinguish between the unchanging core of Islam and its external layer which was open to change. He stressed the unity of God(tawhid) as the foundation of Islam's integrated worldview, saw no conflict between Islam and modernity, and stressed that religion and reason were not contradictory, but complemented each other as the two sources of Islam. Indeed, Islam had early on bestowed rationality to the West but had then neglected it. Abduh wanted to reform society through discovering the real intent of Islam's unchanging fundamental principles and then implementing them in educational and social reforms, as well as through selectively appropriating aspects of the West not contrary to Islam (Ibid).

2.6.3 Muhammad Rashid Rida, (1865-1935) continued with Afghani's and Abduh's call for a reinterpretation of Islam and the development of a modern Islamic legal system. However he gradually became more critical of the West and its growing cultural impact on Egypt, and more sympathetic to Wahhabism. He too rejected the blind acceptance of medieval formulations of law, and wanted to regenerate Islam by going back to the model of the pious ancestors (salaf) Muhammad, his Companions, and the (Khulafa-urrashidun) Caliphs which included the practice of a pure and rational Islam free from superstition, as well as a just and prosperous Islamic society and state. Islam was self-sufficient and comprehensive and had no need to imitate the West, but must return to its original sources. He stressed that full implementation of Islamic law required the existence of a truly Islamic government which could only be a restored Caliphate. This government would function through compulsory consultation (Shura) between the ruler and the representatives of the community, the "people who lose and bind" (ahl al-hall wal-'aqd)(Ibid).

2.6.4 Hassan al-Banna (1906-1949) Banna combined a drive to reform Islam along salafilines with efforts to practically upgrade the condition of the deprived masses by mutual-aid and self-help. He demanded Muslims go back to the practice of the early normative period of Islam, and claimed that only the Quran and the best attested hadith should be the sources of Shari'ah. Hassan Al-Banna saw Islam as an integrated, self-sufficient, and comprehensive social and political system based on tawhid the Onness of Allah which must be implemented in an Islamic state there could be no separation between state and religion. It was the implementation of Shari'ah that made a government truly Islamic, so this implementation was a primary goal of the movement. The constitution of the Islamic state was the Qur'an, and its government was to operate through consultation (Shura)(Adam, 1933).

2.6.5 Sayyid Qutb (1906-1966):- Egyptian thinker an activist, a renowned Islamic scholar was born in Asyut Upper Egypt on $9^{\text {th }}$ October 1906. His family live in the village of Mosha in the province of Asyut, his sixth grandfather was originated from India Alfaqir Abdullah. Sayyid father, Qutb Ibrahim was a kind of generous and benevolent person. He was a religious pious and politically conscious man. Sayyid mother held from respectable family in the village. She had great love for Islam, the Qur'an and Sunna of the Prophet (SAW). She instilled these attributes in the minds of Sayyid. Her devotion to Qur'anic recitation and charity was remarkable. His education, Sayyid Qutb began his education with his parents. When he reached the aged of 6 joined primary 
school where he memorised the Qur'an in 3 years. Sayyid loved reading books. The principle of the school used to lend him two books in a week which he finished it and make his own copy before he return the books. In 1920 he travelled to Cairo for further education and he joined Darul-Ulum and he became a prolific writer he wrote many books during his life time such as mile stone, social justice in Islam, in the shade of the Qur'an, his prominent (Tafsir Fi zilal al-Qur'an).

After finishing school started his career as a class room teacher, in the year 1940, he was asked to joined ministry of education and later he was made inspector of primary school in 1944. In November 1948, he was sent to America to study educational system of American Universities, Institutions, and Colleges. After two years he returned back in 1950, and made a proposal to the government seeking for the reformation of educational system in Egypt. However, the government did not response to his request due to this he felt frustrated and resigned his post. And one year after his resignation the government implemented his reform. In July, 1952, there was a military coup led by Jamal Abdel-Nasir in Egypt where by the Monarch was overthrown. The Muslim Brotherhood supported that coup; Sayyid Qutb played a significant role in supporting that coup with the intension to established Shariah in accordance with Qur'an and Sunna. In the early stage of the revolution he was regarded as the mentor and guider of the revolution. In many occasion he was invited to deliver a talks on national issues and aspects of Islam, but he was vocal and transparent he never compromised his ideas and principles.

Moreover, He was totally rejected the idea of socialist and nationalist movement which he felt that they are against Islamic Shariah in Egypt. This is the genesis of disagreement between him and the President Jamal Abdel Nasir. He continues with his writing books and in 1952, started writing his important book in the shade of Qur'an which he completed when he was in prison. Sayyid Qutb was jailed 3 times for different allegations. In a nutshell, in 1965, the court pronounced a verdict on Sayyid Qutb and other members of Muslim Brotherhood and he was sentenced to death together with the two members, while the rest of 25 life imprisonment. In reaction to the verdict Sayyid Qutb said that "Praise be to Allah! I have worked 15 years to gain this Shahada." And on $29^{\text {th }}$ August 1966 Sayyid Qutb and two others were hanged (Harris, 1964).

\subsubsection{His Political Thought}

Sayyid Qutb consider both capitalism and communism as the worst ideologies and enemy of mankind. He never supported man made ideologies in his life. He is against the idea of nationalism because he felt that it the process of weakening Muslims to accept defeat and sometime fought each other. According to him all ideologies and movement that are originated from the so-called western philosophy of eighteen century had lost their vitality. He contended that the ideology of capitalism is one of the enemies of mankind, because gradually exploited the people through various stages and means. Also he criticised communism due to its treatment of the people as robots. He condemned communism for not providing freedom and liberty to the people to exercise their free will of choosing any way of life or religion. Sayyid Qutb divided the word into three. The western bloc, the eastern bloc, and the Neutral, he viewed that both western and eastern blocs competed with each other to dominate the whole world, while the third bloc was forced to remain valueless and insignificant in all aspects. $\mathrm{He}$ is totally against the Idea of non-alignment because he argued that is the idea that represents artificiality (Ibid).

\section{* Islamic Shariah}

After the coup of 1952, he insisted for the implementation of Islamic Shariah with justice and accountability, but Jamal Abdel-Nasir refused and instead advocated for socialism and nationalism hence Sayyid Qutb withdraw his 
support and failed to compromised with the government. Sayyid Qutb asserted that the only means that can brings about sanity and progress to the Ummah must be through the implementation of Islamic law based on Qur'an and Sunna and not man-made ideologies.

\section{- The Muslim bloc}

Sayyid Qutb call on the Muslim nation to unite themselves as a third force namely Muslim bloc under the banner of Islam. He believed that Muslim bloc would provide all necessities and needs which are essential for mankind with rational approach that give good shape of life. This bloc would believe in real social justice, freedom and all kinds of benefits and facilities for every individual. He says that it will maintain the balance between the two opposing structures capitalism and communism.

\section{* Concept of society}

Sayyid Qutb divided the concept of society into two compartments, the Islamic society and Jahiliyya society, which he means civilised society and backward society. According to him an Islamic society is the civilised society that recognised the laws of Allah, the Shariah as the laws of the land. Islamic society asserts the unity of Allah and its sincere observance both in words and deeds. It did not accept any sovereignty of man and only accept absolute sovereignty of Allah. On the other hand, the Jahiliyya society is the backward society that is antithetical to Islam as a complete ways of life. Islam neither goes along with it nor those it agree with its doctrines and character. The Jahiliyya society encourages the worship of man by man domination of one power over the other for the sake of power, ideologies, or material ends.

\section{- Sayyid Qutb on education}

Sayyid Qutb was totally against the system of education which is given under the patronage or supervision of the Jews, Christians, and communists which brain wash young Muslims. He maintained that Muslim children should not obtained education on Islam from Jews, Christians, and orientalists. He asserted that the so-called modern education as advocated by missionaries in missionary schools was part of the conspiracy to divorce Islam from the Muslims; He quoted the word of Samuel Zwemer "Our mission is to have Muslim leave Islam and make them subservient to our teachings, our influence, and our ideas.......Everyone who graduates from these schools abandon Islam in actuality if not in name." Therefore, these are some of the brief ideas of Sayyid Qutb to the contemporary Islamic movement (Ibid).

2.6.6 Abu A'la Al-Mawdudi a great Islamic thinker, philosopher, reformer, an activist founder of Jama'at Islami in India he was born in India on $25^{\text {th }}$ September, 1903. He was born from a very famous and religious family. He was a strong believer with Qur'an and Sunnah. Mawdudi was totally against western democracy in the early stage. He started his early education from his parent same like Qutb he developed interest in languages, especially Arabic, he mastered Qur'an and Hadith also learned mathematics and science subjects. His started his career as a journalist, and joined many Islamic movements before forming his organization. In 1941 Mawdudi formed Islamic movement Jama'at Islami in Lahore Indian sub-continent and after the petition of India, Mawdudi migrated to Pakistan and developed in writing books, journals, and pamphlets. In the early stage the movement was based on Tajdid (Reform) not politics. However, when times goes on Jama'at Islami turned to political party and participated fully in political arena (Ahmad, 1967).

\subsubsection{Allama Mawdudi's Political Thought}

Mawdudi's political system was constituted based on four basic principles; The first principle of Mawdudi's thought, was a concrete comprehensive presentation of Islam as a complete way of life, which encompasses all aspects of life, individuals, groups, and it also deals with political, economic, and social aspects. The second 
principle is that the purpose of the meaning of life is nothing but to serve or worship Allah (S.W.T). In the third principle Mawdudi never perceived Islam as the static religion, to him Islam is a complete and dynamic whenever there is problem which were not found in Qur'an and Sunna he use Ijtihad to find the solution of the problem. The fourth principle argued that all the injustice, chaos and problems are due to the domination of man by man.

\section{* The Concept of Islamic State and Shariah}

According to him by Islamic state he never means that the state should comprised only Muslims, but rather the Islamic state should be based on Islamic principles of Shariah, and non-Muslim should be given their rights and privileges. He profound the principle of Islamic state, according to him the principles of Islamic state was based on three creeds Tawheed, Risalah, and khilafah. The second principle was the purpose of an Islamic state and its characteristic which he argued should be based on sovereignty, khilafah, and Shariah. The third principle was the directive principles of state policy (Islamic manifesto) (Ibid).

\section{- Mawdudi's Organs of Government}

According to him the organs of government should be divided into three as follows:-

Shura/Parliament had the responsibility of making laws based on Qur'an and Sunna it must consist people who are knowledgeable Ahl al-Hall wal 'Aqad. Another organ is Amara/Executive had the responsibility of execution or implementation of law based on Islamic principles and they should secure directives from Allah (S.W.T) and rules according to Qur'an and Sunna. The last organ of government in Mawdudi's thought was Qada/Judiciary that had the responsibility of interpreting the law, this consist of judges which they must exercise their function in line with Qur'an and Sunna. They have to follow what was revealed by Allah (S.W.T). Mawdudi accepted the clear separation of power between these three organs; each organ must be independent and answerable to the chief of the executive who is the head of state and he too is answerable to Allah.

\section{* Citizenship in an Islamic State}

Mawdudi identified two types of citizenship in an Islamic state; the Muslims and the non-Muslims (Ahlul dhimmis). He argued that the Muslim citizens must perform all the socio-political directives of the state. They are vested with many obligations and sacrifices in order to defence the state. They enjoy the rights of choosing the head of state, membership of law making bodies, and appointment of the key position in an Islamic state. Whereas, the non-Muslims enjoy civil liberties and protection with the condition of paying the tax (Jizya) and within the non-Muslim women, children, elderly and disable people were exempted for paying the tax (Ibid).

\section{Conclusion}

At the end of the $19^{\text {th }}$ and $20^{\text {th }}$ century Islamic movements have become very popular within the Muslim society all over the world, led by these Islamic educated elites. The main aimed of these movements was the implementation of Islamic oriented society. However, the establishment of an Islamic system does necessitate the creation of an Islamic state, and the mainstreams of Islamic movements have become major actors within the system, while the violent radicals continue to confront the state. The moderates demand participation as equals in the democratic process, while the extremists threaten violence and revolution.

\section{References}

\section{Abu-Rabi, I .(2004). Contemporary Arab Thought: Studies in Post-1967 Arab Intellectual}

\section{History: London Pluto Press}

Adam, C. (1933). Islam and Modernity in Egypt, London: Oxford University Press.

Ahmad, A. (1967). Islamic Modernism in India and Pakistan 1857-1965, London: Oxford 
The Role of Contemporary Islamic Movement towards Social and Political Changes of Modernity

Ibrahim Suleiman

University Press.

Deukmejian, R. H. (1985). Islam in Revolution: Fundamentalism in the Arab world. Syracuse,

N. Y: Syracuse University Press.

Enayat, H. (1982). Modern Islamic Political Thought, London: Macmillan Press.

Espositor, J. L. (1990). The Iranian Revolution:Its Global impact.Miami. International University Press.

Harris, C. (1964). Nationalism and Revolution. Egypt.

Tibi, B. (2000). The Challenge of Fundamentalism; Political Islam and the New World

Disorder, Updated Edition, Berkeley.

Zeenath, k. (2005). Comtemporary islamic political thought: a study of eleven thinkers. Kuala Lumpur, malaysia: Ampang Press Sdn Bhd.

Copyrights

Copyright for this article is retained by the author(s), with first publication rights granted to the journal. 